\title{
IMPORTANCE OF THE DIAGNOSIS AND TREATMENT OF MESIODENS IN A PEDIATRIC PATIENT: CASE REPORT ${ }^{1}$
}

\author{
A IMPORTÂNCIA DO DIAGNÓSTICO E TRATAMENTO DE \\ MESIODENS EM PACIENTE INFANTIL: RELATO DE CASO
}

\author{
Danieli Londero da Silveira ${ }^{2}$, Cáren Coronel da Silva ${ }^{3}$, \\ Bianca Zimmermann dos Santos ${ }^{4}$ e Alice Souza Pinto ${ }^{5}$
}

\begin{abstract}
This study presents the clinical case of an eight-year-old male patient who visited the Pediatric Dentistry Clinic of Ingá (UNINGÁ) complaining of dissatisfaction with his smile. The clinical and radiographic examination revealed a supernumerary tooth between the maxillary central incisors (mesiodens). Treatment consisted of surgical removal of the mesiodens and restorative clinical interventions. The patient was then sent for orthodontic treatment for complete functional and esthetic restoration. This work addresses the etiology, diagnosis, incidence/prevalence, treatment according to location and age group as well as clinical and radiographic aspects of mesiodens. The present case shows that, when planned in an integrated manner and performed on a properly selected patient, the surgical removal of mesiodens achieves satisfactory results and improves the child's quality of life.
\end{abstract}

Keywords: Supernumerary teeth, Diagnosis, Pediatric dentistry, Surgical treatment, Case report.

\section{RESUMO}

Este trabalho tem como objetivo apresentar um caso clínico, no qual um paciente do sexo masculino, 8 anos de idade, compareceu a Clínica de Odontopediatria da Faculdade Ingá - UNINGÁ, queixando-se de insatisfação com seu sorriso. Após exame clínico e radiográfico, foi diagnosticada a presença de um dente supranumerário entre os incisivos centrais superiores (Mesiodens). O tratamento consistiu na remoção cirúrgica do Mesiodens e intervenções clínicas restauradoras. Após, o paciente foi encaminhado para tratamento ortodôntico para completo reestabelecimento funcional e estético. Além do relato de caso, este trabalho aborda a etiologia, diagnóstico, incidência/prevalência, tratamento de acordo com a localização e faixa etária, bem como, aspectos clínicos e radiográficos do Mesiodens. O caso relatado evidencia que o procedimento cirúrgico quando planejado de forma integrada, e executado em paciente adequadamente selecionado, proporciona resultados satisfatórios e melhoria da qualidade de vida da criança.

Palavras-chave: Dentes supranumerários, Diagnóstico, Odontopediatria, Tratamento cirúrgico, Relato de caso.

\footnotetext{
${ }^{1}$ Informações do autor. E-mail: ? Relato de caso

${ }^{2}$ Autora. Odontopediatra e Mestre em Endocrinologia (UFRGS). E-mail:danielilondero29@gmail.com

${ }^{3}$ Colaboradora. Mestre em Saúde Materno Infantil - Universidade Franciscana (UFN). E-mail: carencoronel_sm@ hotmail.com

${ }^{4}$ Co-orientadora. Docente do curso de Odontologia e do Mestrado Profissional Saúde Materno Infantil - Universidade Franciscana (UFN). E-mail: biancazsantos@hotmail.com

${ }^{5}$ Orientadora. Docente do curso de Odontologia - Universidade Franciscana (UFN). E-mail: alicespinto@hotmail.com
} 


\section{INTRODUCTION}

Supernumerary teeth are those that exceed the normal dentition. This anomaly is known as hyperdontia and the most common type is mesiodens, which is a small, cone-shaped, supernumerary tooth located between the maxillary central incisors (ASSED et al., 2005; SHIH et al., 2016). Mesiodens can affect the normal eruption of the permanent teeth and can cause root resorption, crowing, occlusal problems, diastema and the formation of a cyst; it can also predispose the area to subacute pericoronitis, gingivitis and periodontitis (ASSED et al., 2005). Such teeth are located in the anterior region of the maxilla in $93.2 \%$ of cases and are the etiological factor of impaction in $7.05 \%$ of patients (DMYTRENKO et al., 2018).

Despite being rare in the primary dentition, the diagnosis of mesiodens is fundamental to the normal development of the occlusion. In patients in the growth phase, problems caused by supernumerary teeth can lead to the inadequate development of the forming bone bases, which can be irreversible if perpetuated until the stages of bone maturation. An abnormal number of teeth is an important etiological factor of complications in the development of the occlusion and it is fundamental to identify this condition in the routine practice of pediatric dentistry (GIRONDI, 2001; DOTTO et al., 2002; CECCHI, 2003).

The diagnosis of supernumerary teeth is generally achieved based on clinical and radiographic examinations. Moreover, treatment differs from one case to another depending on the location of the tooth and consequent complications. Treatment options include monitoring, removal and orthodontic alignment (PAROLIA et al., 2011; PEREVERZEVA, 2013; ATA-ALI et al., 2014; FERRAZZANO, 2014).

The aim of the present study was to describe a clinical case of an eight-year-old boy with a supernumerary tooth between the permanent maxillary central incisors, addressing the importance of the correct diagnosis and adequate treatment plan. This paper also discusses the incidence/prevalence, treatment based on location and age group as well as clinical and radiographic aspects of mesiodens.

\section{CASE REPORT}

An eight-year-old male patient visited the Pediatric Dentistry Clinic of the Ingá University Center (UNINGÁ) in the city of Santa Maria (southern Brazil) accompanied by his legal guardian. The main complaint was dissatisfaction with the smile due to the space between the central incisors. The guardian reported that the child had no health problems. The intraoral examination revealed that the child was in the mixed dentition phase and had plaque buildup, especially on the cervical faces of the maxillary incisors. 
A panoramic radiograph was requested for the evaluation of the eruption pattern as well as dental and skeletal growth and development. The radiographic exam revealed the presence of a supernumerary tooth between the maxillary central incisors (mesiodens), as shown in Figure 1.

After the clinical and radiographic analysis, cone beam computed tomography was performed for a better determination of the three-dimensional location of the supernumerary tooth, adjacent teeth and anatomic structures involved (Figure 2) to enable the planning of the surgical procedure with greater precision. After the analysis of the exams, the decision was made with the participation of the child's guardian to perform the surgical removal of the supernumerary tooth.

It should be pointed out that the relationship is the major difference between the treatment of children and adults. With children, the relationship is established among the dentist, child and parents/guardians. In the present case, this unifying contact occurred, as the parents participated fully and prepared the child. Regarding behavior and child management techniques, the patient was very cooperative during the procedure and the "tell, show and do" technique was employed to establish good communication with the patient, diminish his fear and anxiety in the face of the unknown and build a relationship of trust.

For the surgery, antisepsis of the skin was performed with povidone $10 \%$. Oral antisepsis was performed by rinsing the mouth with chlorhexidine $0.12 \%$ and the surgical field was positioned. Next, the topical anesthetic was administered and the infiltrative anesthesia was administered to the right and left sides of the anterior maxillary region and anterior palatal region using two cartridges of mepivacaine 2\% with epinephrine 1:100.000 (Mepinor, DFL- Brazil). The incision was then made (Figure 3), followed by the detachment of the periosteum (Figure 4) with the aid of the syndesmotome.

After exposure of the bone tissue, the supernumerary tooth (Figure 5) was removed with the aid of the elevator and periotome. The region was inspected and irrigated with saline solution to remove tissue and bone fragments. The flap was then sutured in place with black monofilament nylon thread with a $3 / 8$ triangular stainless-steel needle measuring $2.0 \mathrm{~cm}$ in length (Figure 6).

The patient was medicated with ibuprofen $100 \mathrm{mg} / \mathrm{ml}$ (30 drops every six hours for three days) and mouth rinsing with chlorhexidine $0.12 \%$ (15 $\mathrm{ml}$ for 30 second every 12 hours for seven days) before and after the procedure. The medication was prescribed before the surgical procedure as a preventive measure to avoid pain and discomfort stemming from the procedure. The patient and guardian were given instructions regarding postoperative care. At the seven-day follow-up, good healing of the surgical site was observed (Figure 7). The guardians reported that the postoperative period was relatively fast, with no symptoms of pain or swelling.

Treatment consisted of the surgical removal of the mesiodens, restorative interventions and the extraction of teeth 53, 63 and 64. Orthodontic treatment (fixed space maintainer) and follow-up were planned to restore adequate function and esthetics. 
Figure 1 - Panoramic radiograph showing supernumerary tooth (mesiodens).

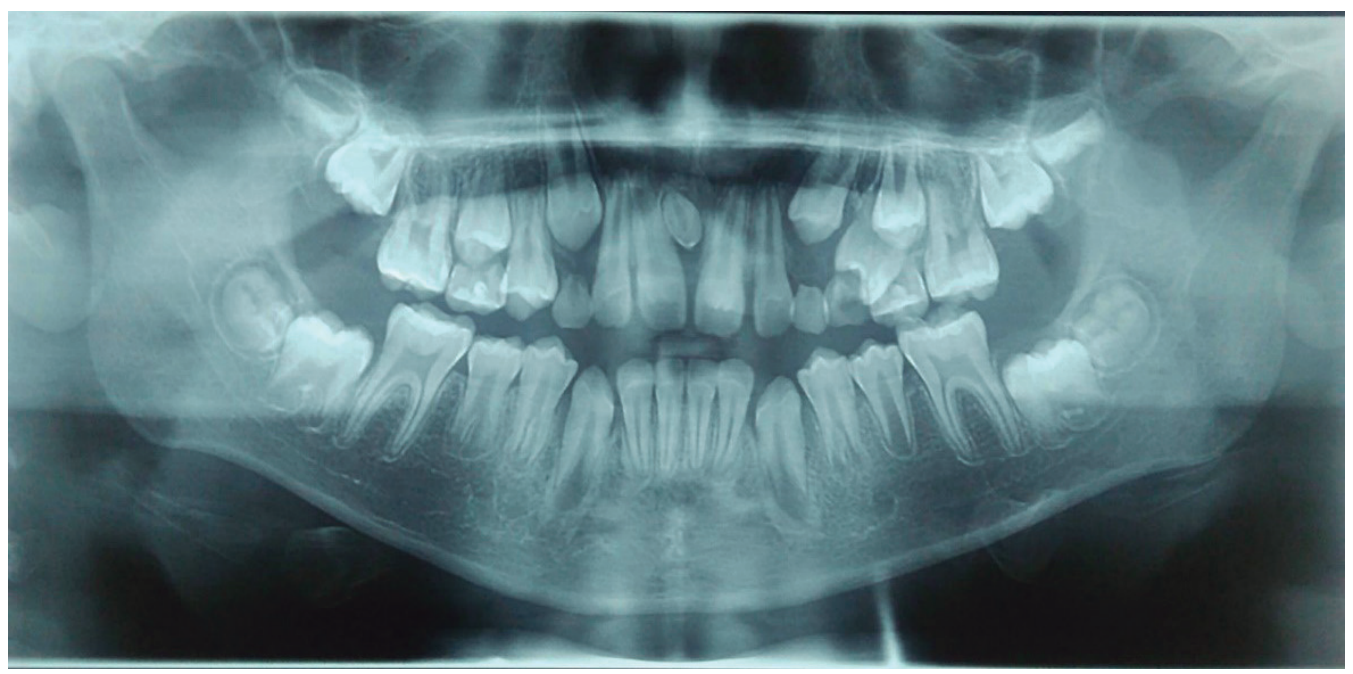

Figures 2A, 2B e 2C - 3D cone beam computed tomography in different slices.

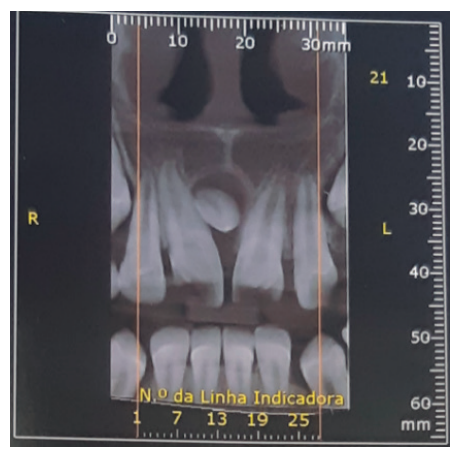

A

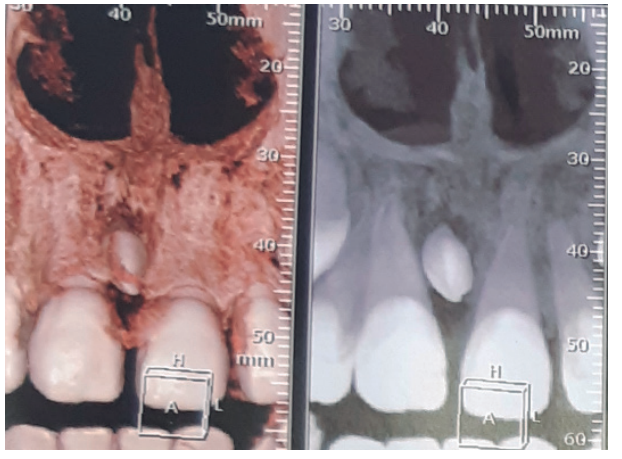

$\mathrm{B}$

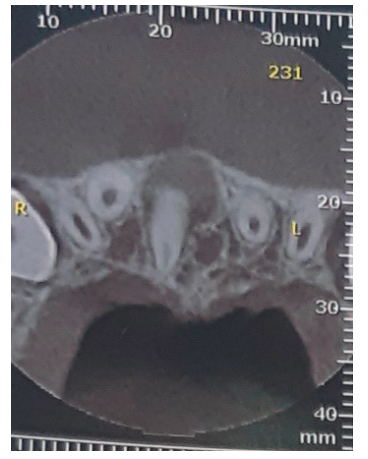

$\mathrm{C}$

Figures 3A e 3B - Infiltrative anesthesia with local hemostasis and marking of incision.

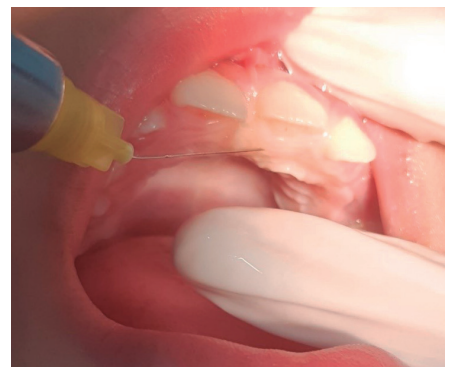

A

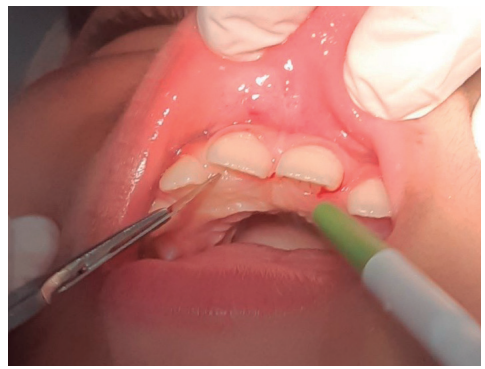

B

Figures 4A e 4B - Detachment of flap in vestibular and palatal directions. 


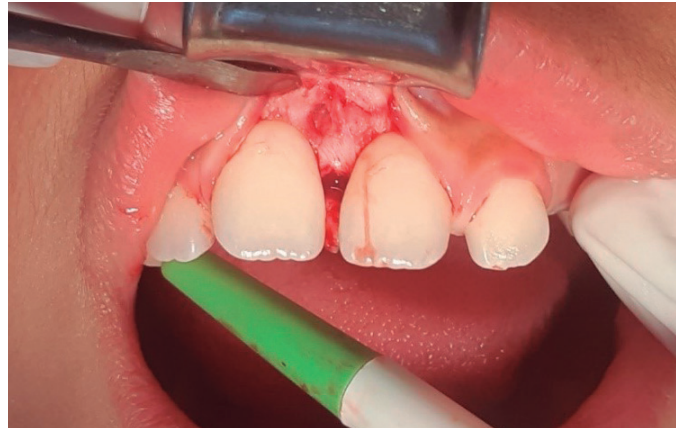

A

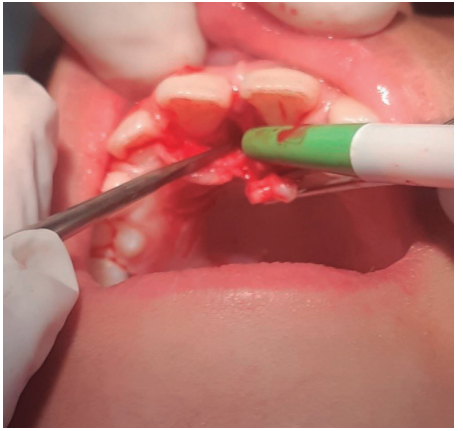

B

Figures 5A e 5B - Removal of supernumerary tooth (mesiodens) measuring approximately $15 \mathrm{~mm}$.

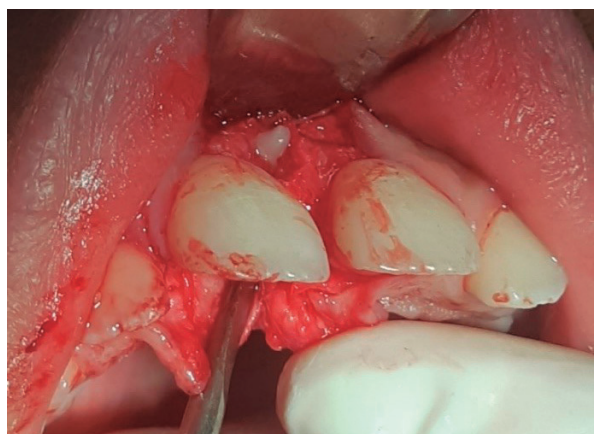

A

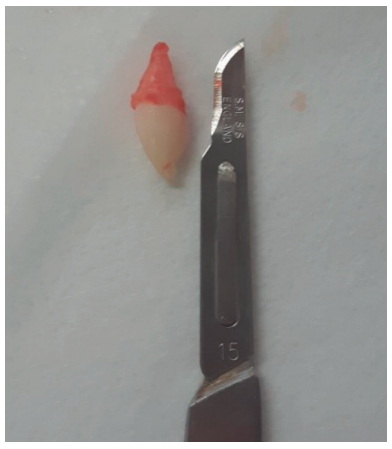

B

Figure 6 - Finalization of surgery - black monofilament nylon thread placed with $3 / 8$ triangular stainless-steel needle measuring $2.0 \mathrm{~cm}$ in length.

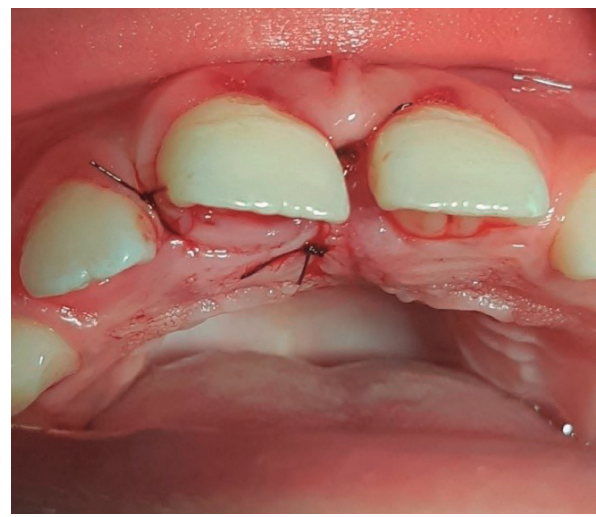

Figure 7 - Appearance seven days after surgery: adequate healing.

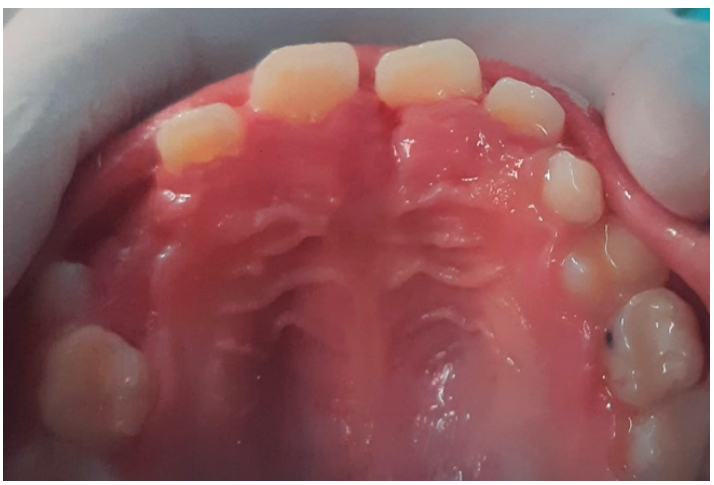




\section{DISCUSSION}

Supernumerary teeth in the anterior region of the maxilla cause several functional and esthetic problems, such as the delayed eruption of the permanent tooth, the occurrence of diastema and rotated teeth, abnormal bone growth, abnormal direction and eruption of the antagonist tooth, brushing difficulties, a predisposition toward gingivitis and caries, abnormal chewing pattern and occlusal problems. The radiographic analysis reveals other complications, such as impaction, deviation of the normal eruption path, root resorption, the loss of the adjacent tooth and cysts or tumors (KUMAR et al., 2013; ANEGUNDI et al., 2014). Considering the complications associated with mesiodens, an early diagnosis improves the chances of minimally invasive, less complex treatment, enabling the balanced growth and development of structures, which is ideal when the patient is a child.

A detailed patient history and clinical examination are fundamental to the success of treatment and can indicate the diagnosis when investigating the eruption sequence and chronology, number and positioning of teeth and abnormalities in the color, shape, size and mobility of the teeth in the dental arch, occlusion and supporting bone structures (STRINGHINI et al., 2015).

For the diagnosis of supernumerary teeth, complementary radiographic and tomographic exams are essential (NEVILLE et al., 2009). In the present case, the supernumerary tooth was diagnosed by a panoramic radiography and cone beam computed tomography. However, there is no standard protocol for the treatment of supernumerary teeth that can be used in all cases (ZIEGLER et al., 2013).

Figure 8 - Factors that should be considered in treatment plan.

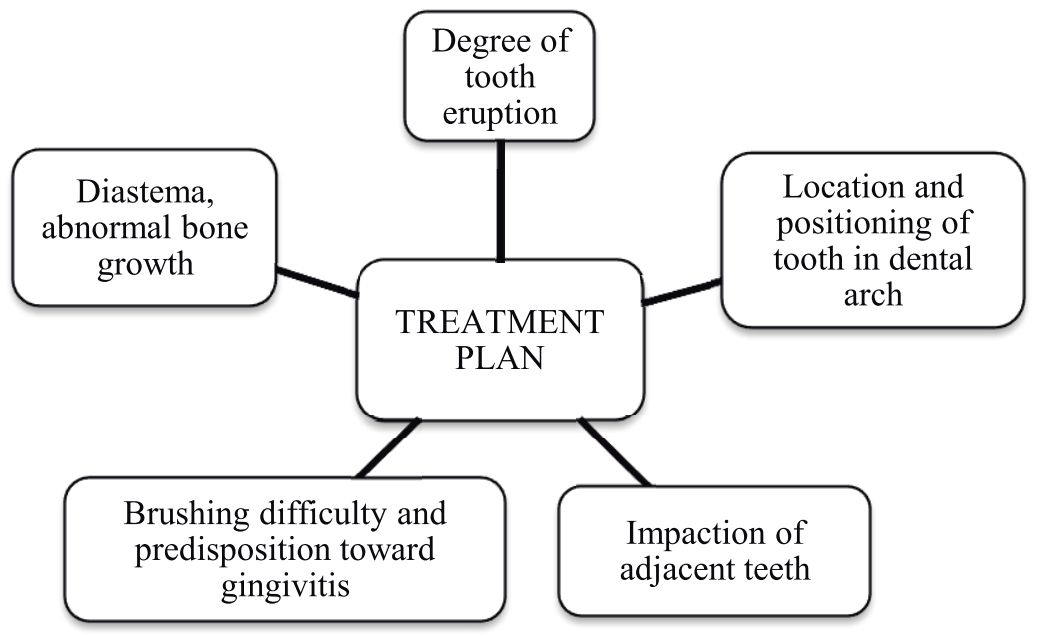

The factors that should be considered when establishing the treatment plant (Figure 8) are the degree of tooth eruption, location and positioning of the tooth in the dental arch, the impaction of adjacent teeth leading to pathological processes or changes in adjacent anatomic structures, esthetic, functional and psychosocial impacts, and the need for orthodontic treatment (NEVILLE et al., 2009; MEIGHANI et al., 2010; MOHAN et al., 2012; LARA et al., 2013). The stage of tooth formation should 
also be considered, especially with regards to root formation of the supernumerary and adjacent teeth (STRINGHINI et al., 2015). After the evaluation of these factors in the present case (Figure 9), the decision was made to extract the supernumerary tooth, which was causing diastema and the rotation of the maxillary central incisors, hindering hygiene and predisposing the child to gingivitis. This conduct was taken to preserve the anatomic structures, facilitate and stimulate adequate oral hygiene and avoid more complex treatments in the future.

Figure 9 - Factors encountered in clinical case.

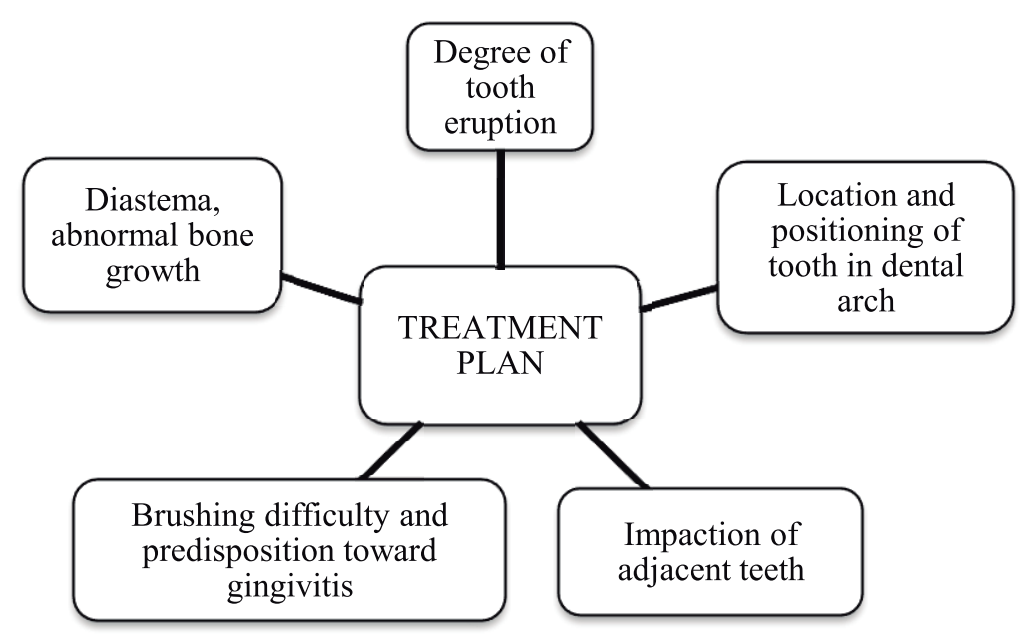

\section{FINAL CONSIDERATIONS}

The conclusion of the present case demonstrated that the early diagnosis of mesiodens through routine radiography is fundamental in pediatric care to ensure more conservative interventions.

Mesiodens can cause occlusal changes that affect both function and esthetics. Thus, early diagnosis and intervention in children in either the primary or mixed dentition phase favors more conservative treatment, which is ideal for children and considerably diminishes the need for more complex, invasive interventions in the future, such a dental traction and corrective orthodontics.

Several favors determine whether the intervention should be performed earlier or later, such as the patient's age, his/her capacity to tolerate a surgical procedures, the stage of tooth development, the proximity of the mesiodens to the roots of the permanent incisors, the risk of surgical trauma and the amount of bone removal. Therefore, a careful, individualized evaluation of each case is essential. In the present clinical case, an integrated approach favored decision making with regards to an adequate treatment plan for a pediatric patient and a successful surgical procedure.

\section{CONSENT}

The images and information were used with the consent of the legal guardian. 


\section{REFERENCES}

ANEGUNDI, R.T. et al. Prevalence and characteristics of supernumerary teeth in a non-syndromic South Indian pediatric population. Journal of Indian Society of Pedodontics and Preventive Dentistry, v. 32, p. 9-12, 2014.

ASSED, A.; BORSATTO, M.C.; FREITAS, A.C. Anomalias dentárias. In: ASSED, S. Odontopediatria: bases científicas para a prática clínica. São Paulo: Artes Médicas, p. 213-253, 2005.

ATA-ALI, F.; ATA-ALI, J.; PEÑARROCHA-OLTRA, D.; PEÑARROCHA-DIAGO, M. Prevalence, etiology, diagnosis, treatment and complications of supernumerary teeth. Journal of Clinical and Experimental Dentistry, v. 6, p. 414-418, 2014.

CECCHI, P. Prevalência de anomalias dentárias de desenvolvimento através das radiografias panorâmicas para documentação ortodôntica de pacientes na faixa etária de 8 a 20 anos na cidade do Rio de Janeiro [Dissertação]. Rio de Janeiro: Universidade Federal do Rio de Janeiro. Faculdade de Medicina. 105 f, 2003.

DOTTO, P.P.; CORTELLI, J.R.; FLORES, J.A. Prevalência de supranumerários em crianças e adolescentes situados na faixa etária de 07 a 12 anos. Revista Odonto Ciência, v. 17, n. 36, p. 200-205, 2002.

DMYTRENKO, M.I.; GURZHIY, O.V. Treatment algorithms of patients with impaction of maxillary central incisors caused by supernumerary teeth. Wiadomości Lekarskie, v. 71, p. 922-932, 2018.

FERRAZZANO, G.F.; CANTILE, T.; ROBERTO, L.; BALDARES, S.; MANZO, P.; MARTINA, R. An impacted central incisor due to supernumerary teeth: a multidisciplinary approach. European Journal of Paediatric Dentistry, v. 15, p. 187-190, 2014.

GIRONDI, J.R. Estudo da prevalência das anomalias dentárias de desenvolvimento, por meio de radiografias panorâmicas, em uma amostra populacional da região bragantina [Dissertação]. São Paulo: Universidade de São Paulo. Faculdade de Odontologia; 79 f. 3, 2001.

KUMAR, D.K.; GOPAL, K.S. An epidemiological study on suprenumerary teeth: a survey on 5000 people. Journal of Clinical and Diagnostic Research, v. 7, n. 7, p. 1504-1507, 2013. 
LARA, T.S. et al. Prevalence of mesiodens in orthodontic patients with deciduous and mixed dentition and its association with other dental anomalies. Dental Press Journal of Orthodontics, v. 18, n. 6, p. 93-9, 2013.

MEIGHANI, G.; PAKDAMAN, A. Diagnosis and Management of Supernumerary (Mesiodens): A Review of the Literature. Journal of Dentistry of Tehran University of Medical Sciences, v. 7, n. 1, p. 41-9, 2010.

MOHAN, S.; KANKARIYA, H.; FAUZDAR, S. Impacted inverted teeth with their possible treatment protocols. Journal of Maxillofacial and Oral Surgery, v. 11, n. 4, p. 455-7, 2012.

NEVILLE, B.W.et al. Patologia Oral e Maxilofacial. 3a. ed. Rio de Janeiro: 2009.

PAROLIA, A.; KUNDABALA, M.; DAHAL, M.; MOHAN, M.; THOMAS, M.S. Management of supernumerary teeth. Journal of Conservative Dentistry, v. 14, p. 221-224, 2011.

PEREVERZEVA, T.V. Supernumerary teeth in the central part of the maxillary alveolar process as the cause of the maxillary central incisor retention and of further development of the maxilla follicular cyst. Application of a composite osteo-plastic material in jaw bones cyst therapy. Stomatologia, v. 92, p. 59-61, 2013.

SHIH, W.Y.; HSIEH, C.Y.; TSAI, T.P. Clinical evaluation of the timing of mesiodens removal. Journal of the Chinese Medical Association, v. 79, p. 345- 350, 2016.

STRINGHINI JUNIOR, E.; STANG, B.; OLIVEIRA, L.B. Dentes supranumerários impactados: relato de caso clínico. Revista da Associação Paulista de Cirurgiões Dentistas, v. 69, n. 1, p. 89-94, 2015.

ZIEGLER, C.M.; KLIMOWICZ, T.R. A comparison between various radiological techniques in the localization and analysis of impacted and supernumerary teeth. Indian Journal of Dental Research, v. 4, n. 3, p. 336-41, 2013. 
